\title{
TEKNIK DATA MINING DALAM PENILAIAN PENGAJARAN GURU BERDASARKAN INDEKS KEPUASAN SISWA
}

\author{
Bob Gary Gerardo ${ }^{1}$, Saifullah ${ }^{2}$, Eka Irawan $^{3}$ \\ ${ }^{1}$ Mahasiswa Program Studi Sistem Informasi STIKOM Tunas Bangsa Pematang Siantar \\ ${ }^{2,3}$ STIKOM Tunas Bangsa Pematangsiantar, Indonesia \\ Email: ${ }^{1}$ bobsirait@gmail.com, ${ }^{2}$ saiful_siantar@yahoo.com,
}

\begin{abstract}
Abstrak
Penilaian kinerja guru merupakan proses analisis dalam rangka menghasilkan pengajaran yang baik. Proses penilaian terhadap kinerja guru di SMP Kartika Pematangsiantar belum begitu detail (rinci). Dengan penilaian yang tidak rinci tersebut, dikhawatirkan akan adanya penilaian yang bersifat subjektif (berdasarkan kepentingan pribadi), yang dapat menimbulkan kecemburuan sosial bagi guru yang tidak menerima prestasi. Dalam penilaian pengajaran guru di butuhkan data kepuasan siswa pada guru. Dalam pengambilan data mengunakan kuesioner dan variabel yang digunakan dalam penilitian ini ada 4 yaitu disiplin, kualitas mengajar, prilaku, dan hubungan sosial. Penelitian ini bertujuan untuk membantu pihak Sekolah dalam meningkatkan kinerja guru khususnya dalam cara pengajaran guru berdasarkan kepuasan siswa dengan menggunakan Metode C4.5.
\end{abstract}

Kata Kunci: Data Mining, Metode C4.5, SMP Kartika, Penilaian Pengajaran Guru Berdasarkan Indeks Kepuasan Siswa

\begin{abstract}
Teacher performance evaluation is a process of analysis in order to produce good teaching. The process of evaluating the performance of teachers in Kartika Pematangsiantar Middle School has not been so detailed (detailed). With such detailed assessment, it is feared that there will be subjective judgments (based on personal interests), which can lead to social jealousy for teachers who do not receive achievements. In the assessment of teacher teaching students need data on teacher satisfaction. In collecting data using questionnaires and variables used in this study there were 4 namely discipline, quality of teaching, behavior, and social relations. This study aims to assist the School in improving teacher performance, especially in the way of teaching teachers based on student satisfaction using C4.5 Method.
\end{abstract}

Keywords: Data Mining, Method C4.5, Kartika Middle School, Teacher Teaching Evaluation Based on Student Satisfaction Index

\section{PENDAHULUAN}

Data mining didefinisikan sebagai suatu proses yang menggunakan berbagai perangkat analisis data untuk menemukan pola dan relasi data agar dapat digunakan untuk membuat prediksi yang tepat [1][2]. Teknik metode atau algoritma dalam data mining sangat bervariasi. Pemilihan metode atau algoritma yang tepat sangat bergantung pada tujuan dan proses secara keseluruhan.

Algoritma C4.5 merupakan salah satu teknik decision tree yang sering digunakan yang menghasilkan beberapa aturan-aturan dan sebuah pohon keputusan dengan tujuan untuk meningkatkan keakuratan dari prediksi yang sedang dilakukan, di samping itu algoritma C4.5 merupakan algoritma yang mudah dimengerti [3]. Algoritma C4.5 termasuk algoritma klasifikasi pohon keputusan yang banyak digunakan karena memiliki kelebihan utama dari algoritma yang lainnya. Kelebihan algoritma C4.5 dapat menghasilkan pohon keputusan yang mudah diinterprestasikan, memiliki tingkat akurasi yang dapat diterima, efisien dalam menangani atribut bertipe diskret dan dapat menangani atribut bertipe diskret dan numeric.

Kemampuan dan perkembangan para siswa/siswi bukan hanya dilihat dari belajar dan fasilitas yang memadai, namun guru juga menjadi faktor yang sangat penting dalam meningkatkan kemampuan siswa/siswi. Guru yang berkompeten dan memiliki kemampuan dibidangnya tentunya akan dapat dengan mudah menyampaikan materi kepada para siswa dan siswi pun dapat dengan mudah menerima materi yang disampaikan oleh para guru. Dalam kegiatan belajar mengajar ada beberapa penyebab ketidakpuasan siswa maupun siswi terhadap kinerja guru diantaranya adalah guru yang sering datang terlambat, kurang baik dalam penyampaian materi , dan guru yang kurang memperhatikan perkembangan siswa maupun siswi. Untuk mendapatkan guru yang berkualitas tentunya pihak sekolah akan melakukan penilaian bagi setiap guru yang mengajar pada sekolah tersebut dengan mengukur tingkat kepuasan siswa ataupun siswi guna memperbaiki serta meningkatkan kualitas sekolah. Setiap siswa maupun siswi tentunya ingin memperoleh pelayanan pendidikan yang baik. Itulah sebabnya perlu diketahui puas atau tidaknya siswa terhadap cara pengajaran guru yang diberikan oleh pihak sekolah. Tujuan dari penelitian ini dilakukan yaitu untuk menganalisa apakah siswa puas atau tidak terhadap cara pengajaran guru dengan menggunakan aplikasi RapidMiner Studio. Hasil dari penelitian ini dilakukan untuk memberikan model aturan dalam menganalisa apakah siswa puas atau tidak terhadap cara pengajaran guru dengan menggunakan Algoritma C4.5.

\section{TEORITIS}

\subsection{Data Mining}

Data mining adalah proses menganalisa data dari perspektif yang berbeda dan menyimpulkannya menjadi informasi-informasi penting yang dapat dipakai untuk meningkatkan keuntungan, memperkecil biaya pengeluaran, 
atau bahkan keduanya [4][5]. Data mining dapat dikatakan sebagai proses mengekstrak pengetahuan dari sejumlah besar data yang tersedia. Pengetahuan yang dihasilkan dari proses data mining harus baru, mudah dimengerti, dan bermanfaat [6].

Secara garis besar, data mining dapat dikelompokkan menjadi 2 kategori utama, yaitu [7]:

a. Descriptive mining, yaitu proses untuk menemukan karakteristik penting dari data dalam satu basis data. Teknik data mining yang termasuk descriptive mining adalah clustering, asosiation, dan sequential mining.

b. Predictive, yaitu proses untuk menemukan pola dari data dengan menggunakan beberapa variable lain di masa depan. Salah satu teknik yang terdapat dalam predictive mining adalah klasfikasi.

\subsection{Konsep Decision Tree}

Decision Tree atau Pohon Keputusan adalah pohon yang digunakan sebagai prosedur penalasan untuk mendapatkan jawaban dari masalah yang dimasukkan. Pohon yang dibentuk tidak selalu berupa pohon biner. Jika semua fitur dalam data set menggunakan 2 macam nilai kategorikal maka bentuk pohon yang didapatkan berupa pohon biner. Jika dalam fitur berisi lebih dari 2 macam nilai kategorikal atau menggunakan tipe numerik maka bentuk pohon yang didapatkan biasanya tidak berupa pohon biner [8].

Decision Tree terdapat 3 jenis Node, yaitu [9] :

1. Root Node, merupakan node paling atas, pada node ini tidak ada input dan bisa tidak mempunyai output atau mempunyai output lebih dari satu.

2. Internal Node, merupakan node percabangan, pada node ini hanya terdapat satu input dan mempunyai output minimal dua.

Lead Node atau Terminal Node, merupakan node akhir, pada node ini hanya terdapat satu input dan tidak mempunyai output.

\subsection{Algoritma $\boldsymbol{C 4 . 5}$}

Algoritma C4.5 diperkenalkan oleh Quinlan (1996) sebagai versi perbaikan dari ID3. Dalam ID3, induksi Decision Tree hanya bisa dilakukan pada fitur bertipe kategorikal (nominal atau ordinal), sedangkan tipe numerik (interval atau rasio) tidak dapat digunakan [8]. Algoritma yang merupakan pengembangan dari ID3 ini dapat mengklasifikasikan data dengan metode pohon keputusan yang memiliki kelebihan dapat mengolah data numerik (kontinyu) dan diskret, dapat menangani nilai atribut yang hilang, menghasilkan aturan-aturan yang mudah di interprestasikan, dan tercepat diantara algoritma-algoritma yang menggunakan memori utama di komputer [10].

Hal penting dalam induksi Decision Tree adalah bagaimana menyatakan syarat pengujian node yang terdiri dari 3 kelompok [8] :

1. Fitur Biner

Fitur yang hanya mempunyai dua nilai berbeda, syarat pengujian ketika fitur ini menjadi node (akar maupun internal) hanya punya dua pilihan cabang. Contoh pemecahannya dapat dilihat pada Gambar 1.

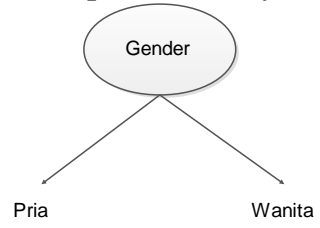

2. Fitur bertipe Kategorikal

Gambar 1. Syarat Pengujian Fitur Biner

Untuk fitur yang nilainya bertipe kategorikal (nominal atau ordinal) bisa mempunyai beberapa nilai berbeda.
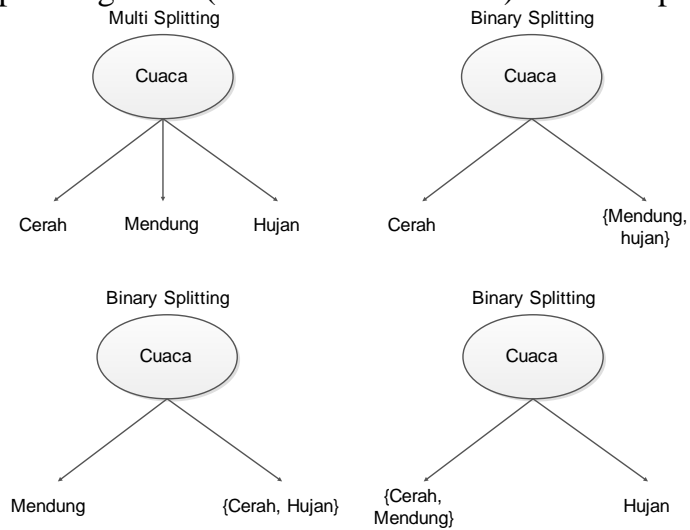

Gambar 2. Syarat Pengujian Fitur Bertipe Nominal 

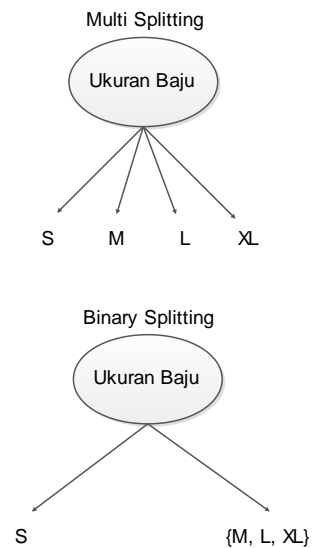
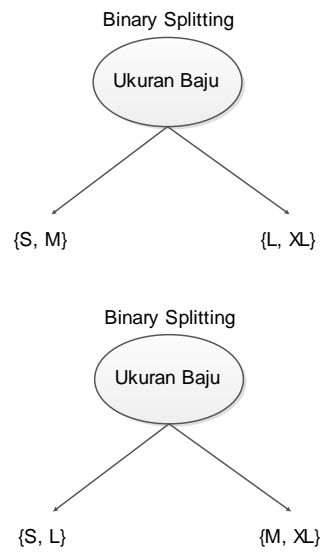

Gambar 3. Syarat Pengujian Fitur Bertipe Ordinal

Secara umum ada 2 fitur bertipe kategorikal, yaitu pemecahan biner (binary splitting) dan pemecahan multi (multi splitting). Kombinasinya disajkan seperti Gambar 2 dan 3 yang pemecahan hanya membolehkan pemecahan biner, seperti Algoritma $C A R T$, maka memberikan kemungkinan jumlah kominbasi sebanyak $\mathrm{s}^{\mathrm{k}-1}$, di mana $k$ adalah jumlah nilai berbeda dalam fitur tersebut.

3. Fitur bertipe Numerik

Untuk fitur bertipe numerik, syarat pengujian dalam node dinyatakan dengan pengujian perbandingan $(A<v)$ atau $(\mathrm{A} \geq v)$ dengan hasil biner, atau untuk multi dengan hasil berupa jangkauan nilai dalam bentuk $v_{i} \leq \mathrm{A}<v_{i+1}$, untuk $i$ $=1,2, \ldots, k$. Untuk cara multi, maka algoritma harus memeriksa semua kemungkinan jangkauan nilai kontinyu. Pemecahan pada fitur numerik disajikan pada Gambar 4.
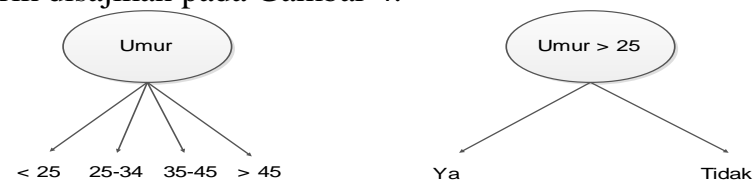

Gambar 4. Syarat Pengujian Fitur Bertipe Numerikal

Kriteria yang paling banyak digunakan untuk memilih fitur sebagai pemecah dalam Algoritma C4.5 adalah Rasio Gain, yang diformulasikan oleh persamaan (1) berikut [9] :

$\operatorname{Gain}(S, A)=\operatorname{Entrropy}(S)-\sum_{i=1}^{n} \frac{|S i|}{|S|} * \operatorname{Entropy}(S i)$

Keterangan :

S : Himpunan Kasus

A : Atribut

$\mathrm{N}$ : Jumlah partisi atribut A

$|\mathrm{Si}|$ : Jumlah kasus pada partisi ke i

$|\mathrm{S}| \quad$ : Jumlah kasus dalam $\mathrm{S}$

Sedangkan perhitungan nilai Entropy dapat dilihat pada persamaan (2) berikut :

$\operatorname{Entropy}(A)=\sum_{i=1}^{n}-p i * \log _{2} \mathrm{pi}$

Keterangan :

S : Himpunan Kasus

A : Fitur

n : Jumlah partisi S

pi $\quad$ : Proporsi dari $S i$ terhadap $S$

\section{ANALISA DAN PEMBAHASAN}

\subsection{Analisa Data}

Dalam penelitian, data yang digunakan akan diolah dari hasil kuesioner yang diberikan kepada siswa-siswi SMP Kartika angkatan 2018 dan 2019. Data yang digunakan terdiri dari :

1. Variabel Disiplin,

2. Variabel Kualitas Mengajar,

3. Variabel Prilaku, dan

4. Variabel Hubungan Sosial. 
Setiap faktor terdiri dari pertanyaan yang diajukan ke siswa yang diberikan. Kuesioner yang telah dilakukan selanjutnya mencari rata-rata dari faktor yang digunakan. Data yang digunakan menggunakan jenis STatiSTik deskriptif dengan memberikan kuesioner kepada siswa SMP Kartika. Kuesioner yang diberikan menggunakan linker 4 yang terdiri dari ST (Sangat Setuju), S (Setuju), KS (Kurang Setuju), dan TS (Tidak Setuju). Kemudian data diolah menggunakan RapidMiner menggunakan Performance yang berfungsi sebagai validasi dan reabilitas data untuk mencari keakuratan data. Data yang akurat maka akan dilakukan pengolahan data untuk mencari hasil dari masalah penelitian dengan menggunakan RapidMiner dan diambil keputusan dari hasil olahan RapidMiner.

\subsection{Perhitungan Algoritma C4.5}

Permasalahan yang sudah dianalisa, selanjutnya penulis melakukan penilaian pengajaran guru berdasarkan indeks kepuasaan siswa dengan menggunakan Data Mining algoritma C4.5. Algoritma C4.5 dilakukan dengan merancangan / membentuk pohon keputusan (decision tree) dengan memilih atribut pada variabel data sebagai akar (node), membuat cabang untuk setiap nilai, membagi kasus dalam cabang, dan mengulangi proses sampai semua cabang memiliki kelas yang sama.

Berdasarkan data yang digunakan maka tahap pertama yang harus dilakukan yaitu menghitung nilai entropy dan gain. Berikut merupakan data yang digunakan :

Tabel 1. Data Kepuasan Siswa

\begin{tabular}{|c|c|c|c|c|c|c|c|c|c|c|c|c|c|}
\hline No & Responden & V1 & $\mathrm{V2}$ & V3 & V4 & Hasil & No & Responden & V1 & V2 & V3 & V4 & Hasil \\
\hline 1 & $\mathrm{R} 1$ & $\mathrm{~S}$ & $\mathrm{~S}$ & $S$ & $\mathrm{~S}$ & Puas & 26 & R26 & ST & $\mathrm{S}$ & $\mathrm{S}$ & $\mathrm{S}$ & Puas \\
\hline 2 & $\mathrm{R} 2$ & ST & S & S & ST & Puas & 27 & $\mathrm{R} 27$ & $S$ & S & S & S & Puas \\
\hline 3 & R3 & ST & S & $\mathrm{S}$ & $\mathrm{S}$ & Puas & 28 & $\mathrm{R} 28$ & S & S & $S$ & $\mathrm{~S}$ & Tidak Puas \\
\hline 4 & $\mathrm{R} 4$ & $\mathrm{~S}$ & $\mathrm{~S}$ & $\mathrm{~S}$ & $\mathrm{~S}$ & Puas & 29 & R29 & ST & ST & ST & ST & Tidak Puas \\
\hline 5 & R5 & ST & ST & ST & ST & Tidak Puas & 30 & $\mathrm{R} 30$ & $\mathrm{~S}$ & $\mathrm{~S}$ & $\mathrm{~S}$ & $\mathrm{~S}$ & Puas \\
\hline 6 & R6 & $\mathrm{S}$ & $\mathrm{S}$ & $\mathrm{S}$ & $\mathrm{S}$ & Puas & 31 & $\mathrm{R} 31$ & $\mathrm{KS}$ & $\mathrm{KS}$ & $\mathrm{KS}$ & $\mathrm{KS}$ & Tidak Puas \\
\hline 7 & R7 & $\mathrm{KS}$ & $\mathrm{KS}$ & $\mathrm{KS}$ & KS & Tidak Puas & 32 & R32 & ST & $\mathrm{S}$ & $\mathrm{S}$ & $\mathrm{S}$ & Puas \\
\hline 8 & R8 & $\mathrm{KS}$ & $\mathrm{KS}$ & $\mathrm{KS}$ & KS & Tidak Puas & 33 & R33 & $\mathrm{ST}$ & $\mathrm{S}$ & $\mathrm{S}$ & $\mathrm{S}$ & Puas \\
\hline 9 & R9 & $\mathrm{S}$ & $\mathrm{S}$ & $\mathrm{S}$ & $\mathrm{S}$ & Tidak Puas & 34 & R34 & $\mathrm{KS}$ & KS & $\mathrm{KS}$ & KS & Tidak Puas \\
\hline 10 & $\mathrm{R} 10$ & S & $\mathrm{KS}$ & S & S & Tidak Puas & 35 & R35 & $\mathrm{KS}$ & TS & TS & $\mathrm{TS}$ & Tidak Puas \\
\hline 11 & R11 & S & $\mathrm{KS}$ & S & $\mathrm{S}$ & Puas & 36 & R36 & ST & $\mathrm{S}$ & $\mathrm{S}$ & $\mathrm{S}$ & Puas \\
\hline 12 & $\mathrm{R} 12$ & $S$ & $\mathrm{~S}$ & $S$ & KS & Puas & 37 & R37 & ST & ST & ST & ST & Puas \\
\hline 13 & $\mathrm{R} 13$ & S & $\mathrm{KS}$ & $S$ & $S$ & Puas & 38 & R38 & $\mathrm{ST}$ & $\mathrm{S}$ & ST & $\mathrm{S}$ & Puas \\
\hline 14 & R14 & S & $\mathrm{KS}$ & ST & ST & Tidak Puas & 39 & R39 & ST & S & ST & $S$ & Puas \\
\hline 15 & $\mathrm{R} 15$ & $\mathrm{~S}$ & $\mathrm{~S}$ & ST & ST & Puas & 40 & $\mathrm{R} 40$ & $\mathrm{ST}$ & S & ST & S & Puas \\
\hline 16 & R16 & ST & ST & ST & ST & Tidak Puas & 41 & $\mathrm{R} 41$ & $\mathrm{ST}$ & $S$ & $\mathrm{~S}$ & $S$ & Puas \\
\hline 17 & $\mathrm{R} 17$ & $\mathrm{KS}$ & $\mathrm{KS}$ & $\mathrm{KS}$ & $\mathrm{KS}$ & Tidak Puas & 42 & $\mathrm{R} 42$ & $\mathrm{~S}$ & $\mathrm{~S}$ & $S$ & $S$ & Tidak Puas \\
\hline 18 & R18 & ST & $\mathrm{S}$ & $\mathrm{S}$ & $\mathrm{S}$ & Puas & 43 & R43 & ST & ST & ST & ST & Puas \\
\hline 19 & R19 & $\mathrm{S}$ & $\mathrm{S}$ & $S$ & $S$ & Puas & 44 & R44 & $\mathrm{KS}$ & $\mathrm{KS}$ & $\mathrm{KS}$ & $\mathrm{KS}$ & Tidak Puas \\
\hline 20 & R20 & ST & ST & ST & $\mathrm{S}$ & Puas & 45 & $\mathrm{R} 45$ & $\mathrm{~S}$ & $\mathrm{~S}$ & $\mathrm{~S}$ & $\mathrm{~S}$ & Puas \\
\hline 21 & $\mathrm{R} 21$ & $\mathrm{KS}$ & TS & TS & TS & Tidak Puas & 46 & R46 & $S$ & S & $\mathrm{S}$ & $\mathrm{S}$ & Puas \\
\hline 22 & $\mathrm{R} 22$ & $\mathrm{~S}$ & $\mathrm{~S}$ & $\mathrm{~S}$ & $S$ & Puas & 47 & $\mathrm{R} 47$ & S & S & ST & $\mathrm{ST}$ & Puas \\
\hline 23 & R23 & ST & $S$ & S & S & Puas & 48 & R48 & S & $S$ & $\mathrm{KS}$ & $\mathrm{TS}$ & Tidak Puas \\
\hline 24 & R24 & ST & ST & $\mathrm{S}$ & $\mathrm{S}$ & Puas & 49 & R49 & $\mathrm{S}$ & $\mathrm{S}$ & $\mathrm{S}$ & $\mathrm{S}$ & Puas \\
\hline 25 & $\mathrm{R} 25$ & $\mathrm{KS}$ & $\mathrm{S}$ & ST & ST & Tidak Puas & 50 & R50 & $\mathrm{KS}$ & TS & S & $\mathrm{KS}$ & Tidak Puas \\
\hline
\end{tabular}

Keterangan :

V1 = Variabel Disiplin

V2 = Variabel Kualitas Mengajar,

V3 = Variabel Prilaku, dan

V4 = Variabel Hubungan Sosial.

Menghitung jumlah kasus, jumlah kasus untuk hasil Puas, jumlah kasus untuk hasil Tidak Puas, dan entropy dari semua kasus dan kasus dibagi berdasarkan atribut Variabel Disiplin, Variabel Kualitas Mengajar, Variabel Prilaku, dan Variabel Hubungan Sosial. Setelah itu, lakukan perhitungan gain untuk setiap atribut.

Tabel 2. Perhitungan Node 1

\begin{tabular}{ccccccc}
\hline Node & & Jumlah Kasus & Puas (S1) & Tidak (S2) & Entropy & Gain \\
\hline \multirow{4}{*}{1} & Total & 50 & 31 & 19 & 0.95804 & \\
& & & V1 & & & 0.356416678 \\
& ST & 19 & 16 & 3 & 0.62925 & \\
\cline { 2 - 5 } & S & 21 & 15 & 6 & 0.86312 & \\
& KS & 10 & 0 & 10 & 0 & \\
& & & & & &
\end{tabular}




$\begin{array}{cccccc}\text { TS } & 0 & 0 & 0 & 0 & \\ & & \text { V2 } & & & 0.285711011 \\ \text { ST } & 7 & 4 & 3 & 0.98523 & \\ \text { S } & 30 & 25 & 5 & 0.65002 & \\ \text { KS } & 10 & 2 & 8 & 0.72193 & \\ \text { TS } & 3 & 0 & 3 & 0 & \\ & & \text { V3 } & & & 0.329033058 \\ \text { ST } & 13 & 8 & 5 & 0.96124 & \\ \text { S } & 28 & 23 & 5 & 0.67694 & \\ \text { KS } & 7 & 0 & 7 & 0 & \\ \text { TS } & 2 & 0 & 2 & 0 & \\ & & \text { V4 } & & & 0.335370829 \\ \text { ST } & 10 & 5 & 5 & 1 & \\ \text { S } & 29 & 25 & 4 & 0.57879 & \\ \text { KS } & 8 & 1 & 7 & 0.54356 & \\ \text { TS } & 3 & 0 & 3 & 0 & \end{array}$

Dari tabel 2 dapat diketahui bahwa pada baris total diketahui jumlah kasus (S) adalah 50, jumlah Puas (S1) sebanyak 31, dan jumlah tidak puas (S2) sebanyak 19. Perhitungan entropy total pada tabel 2 dapat dihitung dengan menggunakan persamaan 1 sebagai berikut:

Entropy $($ Total $)=\left(-\frac{31}{50} * \log 2\left(\frac{31}{50}\right)\right)+\left(-\frac{19}{50} * \log 2\left(\frac{19}{50}\right)\right)=0.95804$

Sementara itu untuk perhitungan entropy setiap atribut sama halnya dengan perhitungan mencari nilai entropy(total). Setelah nilai entropy didapat selanjutnya mencari nilai gain pada setiap atribut. Nilai gain atribut V1 dihitung dengan menggunakan persamaan 2 sebagai berikut :

$\operatorname{Gain}(V 1)=0.95804-\left(\left(\frac{19}{50} * 0.62925\right)+\left(\frac{21}{50} * 0.86312\right)+\left(\frac{10}{50} * 0\right)+\left(\frac{0}{50} * 0\right)\right) \operatorname{Gain}(V 1)=0.356416678$

Untuk perhitungan pada atribut-atribut berikutnya sama seperti perhitungan pada atribut V1. Sehingga diperoleh hasil perhitungan yang ditunjukkan pada tabel 3.2. Dari tabel 3.2 dapat diketahui bahwa atribut dengan gain tertinggi adalah V1, yaitu sebesar 0.356416678. dengan demikian atribut V1 dapat menjadi node akar dan dapat dilihat pada gambar sebagai berikut :

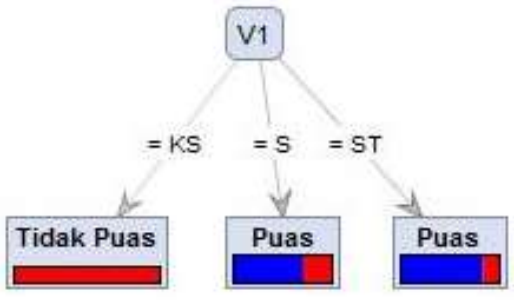

Gambar 5. Node Akar

Dari gambar dapat dilihat bahwa atribut KM(Kilometer) memiliki 3 nilai yaitu KS, S, dan ST. Dari tiga nilai tersebut masih memerlukan perhitungan lebih lanjut. Perhitungan tersebut dapat dilihat pada tabel berikut :

Tabel 3. Perhitungan Node 1.1

\begin{tabular}{lllllll}
\hline Node & & Jumlah Kasus & Puas (S1) & Tidak (S2) & Entropy & Gain \\
\cline { 3 - 7 } & V1-ST & 19 & 16 & 3 & 0.62925 & \\
V2 & & & & & 0.266270437 \\
ST & 7 & 4 & 3 & 0.98523 & \\
S & 12 & 12 & 0 & 0 & \\
KS & 0 & 0 & 0 & 0 & \\
TS & 0 & 0 & 0 & 0 & \\
& V3 & & & & & 0.194266987 \\
& ST & 9 & 6 & 3 & 0.9183 & \\
S & 10 & 10 & 0 & 0 & \\
KS & 0 & 0 & 0 & 0 & \\
TS & 0 & 0 & 0 & 0 & \\
& V4 & & & & & \\
& ST & 6 & 3 & 3 & 1 & \\
S & 13 & 13 & 0 & 0 & \\
KS & 0 & 0 & 0 & 0 &
\end{tabular}




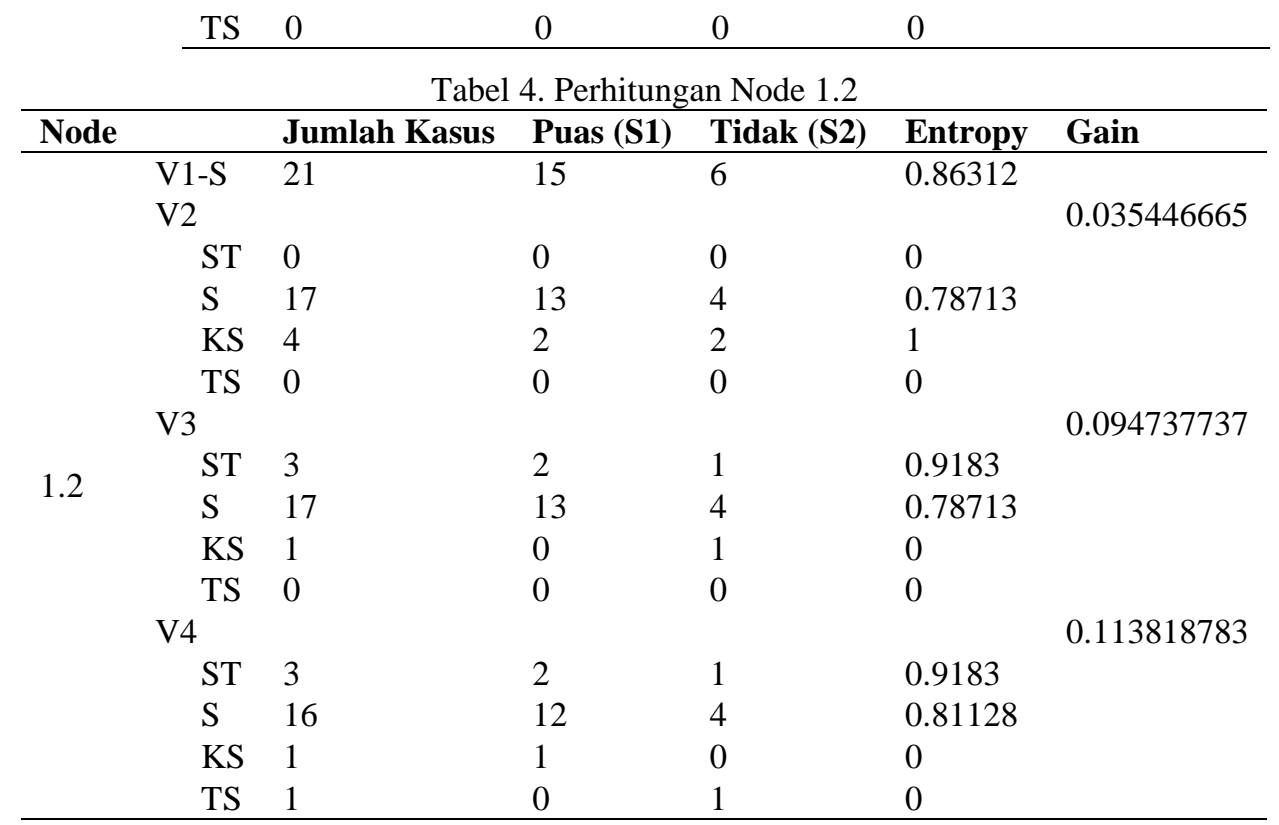

Tabel 5. Perhitungan Node 1.3

\begin{tabular}{|c|c|c|c|c|c|c|}
\hline \multirow[t]{2}{*}{ Node } & & Jumlah Kasus & Puas (S1) & Tidak (S2) & Entropy & Gain \\
\hline & V1-KS & 10 & 0 & 10 & 0 & \\
\hline \multirow{15}{*}{1.3} & $\mathrm{~V} 2$ & & & & & 0 \\
\hline & $\mathrm{ST}$ & 0 & 0 & 0 & 0 & \\
\hline & $\mathrm{S}$ & 1 & 0 & 1 & 0 & \\
\hline & $\mathrm{KS}$ & 6 & 0 & 6 & 0 & \\
\hline & TS & 3 & 0 & 3 & 0 & \\
\hline & V3 & & & & & 0 \\
\hline & ST & 1 & 0 & 1 & 0 & \\
\hline & $\mathrm{S}$ & 1 & 0 & 1 & 0 & \\
\hline & $\mathrm{KS}$ & 6 & 0 & 6 & 0 & \\
\hline & TS & 2 & 0 & 2 & 0 & \\
\hline & V4 & & & & & 0 \\
\hline & $\mathrm{ST}$ & 1 & 0 & 1 & 0 & \\
\hline & $\mathrm{S}$ & 0 & 0 & 0 & 0 & \\
\hline & $\mathrm{KS}$ & 7 & 0 & 7 & 0 & \\
\hline & $\mathrm{TS}$ & 2 & 0 & 2 & 0 & \\
\hline
\end{tabular}

Proses perhitungan dalam mencari nilai entropy dan gain pada node-node berikutnya sama halnya dengan perhitungan untuk mencari nilai entropy dan gain pada node 1. Jumlah kasus yang digunakan disesuaikan dengan jumlah kasus setiap nilai yang ada pada atribut V1. Perhitungan akan terus berlanjut sampai semua atribut yang ada habis terpartisi.

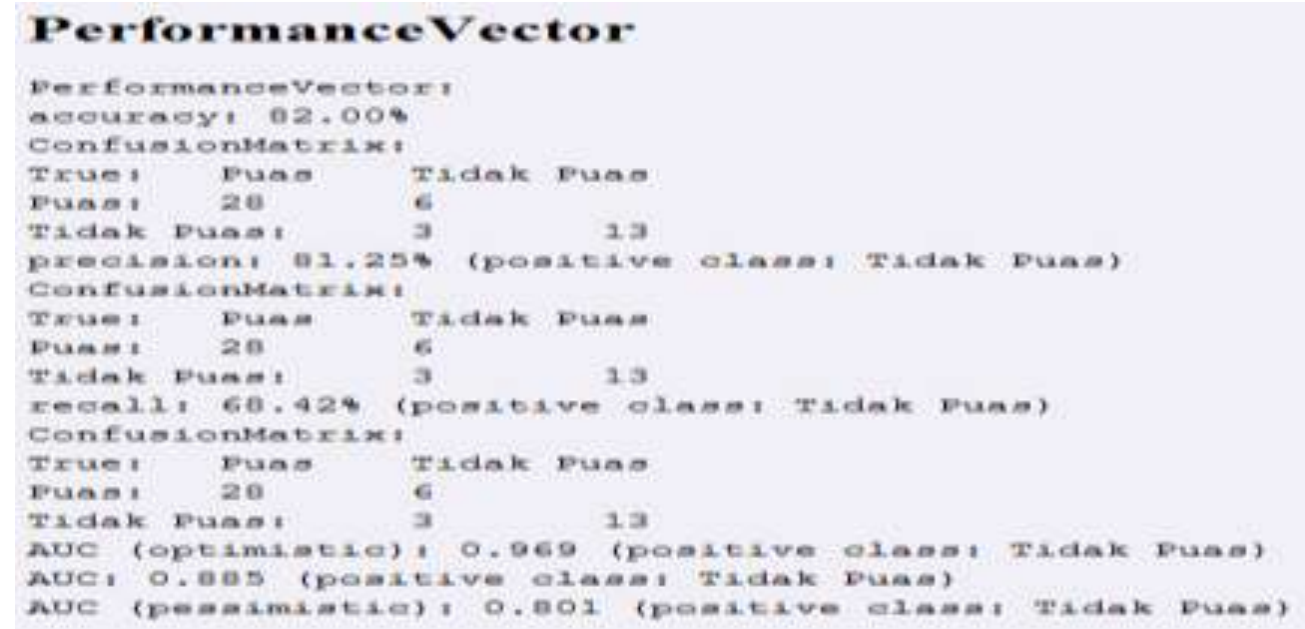

Gambar 6. Detail Performance Vector 
Berdasarkan gambar yang telah dijelaskan di atas, dari proses perhitungan data mining menggunakan algoritma C4.5 dan tingkat keakurasian, dihasilkan suatu informasi baru yaitu dihasilkan tingkat akurasi sebesar $82.00 \%$. Analisa yang dilakukan terhadap tingkat akurasi menggunakan algoritma c4.5 menunjukkan bahwa nilai yang dihasilkan oleh algoritma c4.5 memiliki tingkat kekuatan yang cukup tinggi. Hal ini di buktikan dengan hasil perhitungan yang mencapai nilai $82.00 \%$, Nilai $82.00 \%$ membuktikan bahwa model yang dibangun dapat digunakan untuk melakukan klasifikasi kepuasan siswa

\section{KESIMPULAN}

Berdasarkan pembahasan sebelumnya dapat disimpulkan bahwa penerapan Datamining dengan menggunakan algoritma C4.5 dalam menentukan mengevaluasi kinerja guru pada proses belajar mengajar dapat diterapkan. Sumber data yang digunakan pada penelitian ini adalah data yang diperoleh langsung dari siswa SMP Kartika Pematangsiantar melalui kuesioner. Jumlah data yang data uji sebanyak 50 siswa dengan menggunakan dua kelas. Dari hasil perhitungan Algoritma C4.5 diperoleh klasifikasi dengan variable dominan yaitu V1(Variabel Disiplin). Pengujian data pada Rapidminer 5.3 menggunakan naive bayes dapat menampilkan dua kelas dari hasil klasifikasi dengan tingkat akurasi sebesar $82.00 \%$. dan dapat dikategorikan execellent .

\section{REFERENCES}

[1] G. Wahyuningtyas, I. Mukhlash, And Soetrisno, Aplikasi Data Mining Untuk Penilaian Kredit Menggunakan Metode Fuzzy Decision Tree, J. Sains Dan Seni Pomits, Vol. 2, No. 1, Pp. 1-6, 2014.

[2] C. Fadlan, S. Ningsih, And A. P. Windarto, Penerapan Metode Naïve Bayes Dalam Klasifikasi Kelayakan Keluarga Penerima Beras Rastra, Jutim, Vol. 3, No. 1, Pp. 1-8, 2018.

[3] L. Navia Rani, Larissa Navia Rani , Fakultas Il Mu Komp Uter, Vol. 2, No. 2, Pp. 33-38, 2015.

[4] A. Saleh, Implementasi Metode Klasifikasi Naïve Bayes Dalam Memprediksi Besarnya Penggunaan Listrik Rumah Tangga, Citec J., Vol. 2, No. 3, Pp. 207-217, 2015.

[5] A. P. Windarto, Implementation Of Data Mining On Rice Imports By Major Country Of Origin Implementation Of Data Mining On Rice Imports By Major Country Of Origin Using Algorithm Using K-Means Clustering Method, Int. J. Artif. Intelegence Res., Vol. 1, No. 2, Pp. 26-33, 2017.

[6] P. Soepomo, Penerapan Data Mining Untuk Klasifikasi Prediksi Penyakit Ispa ( Infeksi Saluran Pernapasan Akut ) Dengan Algoritma Decision Tree ( Id3 ), Vol. 2, 2014.

[7] B. M. Metisen And H. L. Sari, Analisis Clustering Menggunakan Metode K-Means Dalam Pengelompokkan Penjualan Produk Pada Swalayan Fadhila, J. Media Infotama, Vol. 11, No. 2, Pp. 110-118, 2015.

[8] Prasetyo, Data Mining Mengolah Data Menjadi Informasi Menggunakan Matlab. Andi, 2014.

[9] M. A. Sembiring, M. F. L. Sibuea, And A. Sapta, Analisa Kinerja Algoritma C4.5 Dalam Memprediksi Hasil Belajar, Jssr, No. February, Pp. 73-79, 2018.

[10] R. K. Amin, Indwiarti, And Y. Sibaroni, Implementasi Klasifikasi Decision Tree Dengan Algoritma C4.5 Dalam Pengambilan Keputusan Permohonan Kredit Oleh Debitur, Vol. 2, No. 1, Pp. 1768-1778, 2015. 